\title{
ACTUAL EVAPOTRANSPIRATION MODEL BASED ON THE IRRIGATION VOLUME OF THE MAIZE FIELDS ON ALFISOLS
}

\author{
Dwi Priyo Ariyanto ${ }^{1 *}$, Komariah $^{1}$, Sumani ${ }^{1}$, and llham Setiawan ${ }^{2}$ \\ ${ }^{1}$ Department of Soil Science, Faculty of Agriculture, Sebelas Maret University, Surakarta, Central Java \\ 57126, Indonesia \\ ${ }^{2}$ Undergraduate Program of Soil Science, Faculty of Agriculture, Sebelas Maret University \\ Submitted: 2018-11-08 Accepted: 2019-02-04
}

\begin{abstract}
Evapotranspiration data are considered important to determine volume and schedule of the irrigation. The purpose of this study is to determine the actual evapotranspiration model based on the volume of the irrigation to obtain an accurate evapotranspiration value on Alfisols with maize plantation. This research is conducted in the experimental field Jumantono subdistrict, Karanganyar regency by the experiment of the maize (Zea mays) on Alfisols. The evapotranspiration model uses the soil correction factor $(x)$ and the irrigation volume (\% ETc). The soil correction factor $(X)$ is calculated by linear regression on actual evapotranspiration (ETa) with crop evapotranspiration (ETc). ETc using reference evapotranspiration (ETo) using the Penman-Monteith model. The results showed that ETa was smaller than ETc in all treatments. The models that can be produced in this study are 3 models. All models applied to produce a determination coefficient $>90 \%$, which all models have a positive relationship. The best actual evapotranspiration model was in total model uses $\mathrm{ETa}=\{0.0403$ $+(0.0085 \times$ Irrigation volume $)\} \times$ ETc, for daily estimation and total one planting estimation; weekly estimation using the weekly model using $\mathrm{ETa}=\{0.4428+(0.0054 \times$ Irrigation volume $)\} \times \mathrm{ETc}$. The errors of both models are $\pm 1 \%$.
\end{abstract}

Keywords: Evapotranspiration, Irrigation Volume, Maize, Penman-Monteith Model, Soil Correction Factor

How to Cite: Ariyanto, D.P., Komariah, Sumani, and Setiawan, I. (2019). Actual Evapotranspiration Model Based on the Irrigation Volume of the Maize Fields on Alfisols. Sains Tanah Journal of Soil Science and Agroclimatology, 16(1): 24-35 (doi: 10.20961/stjssa.v16i1.25218)

Permalink/DOI: http://dx.doi.org/10.20961/stjssa.v16i1.25218

\section{INTRODUCTION}

Water in agriculture is considered important because it supplies the plant needs. The study by IFPRI (International Food Policy Research Institute) and IWMI (International Water Management Institute) that there is a continuing trend which in 2025 competition from urban and industrial growth will limit the

* Corresponding Author:

Email:dp_ariyanto@staff.uns.ac.id amount of water available for irrigation. This will cause the production of food crops to disappear 350,000,0000 metric tons year $^{-1}$ (Rosegrant et al., 2002). The environment will also be continuously damaged, so that water availability for three sectors; agriculture, housing, and industry are declining, even though their utilization has always increased in line with population growth. If the level of investment in the water policy continues and management decreases over the next 20 
years, there will be a decline in food crop production. This shows that increasing water production in irrigated and rainfed land will reduce the problems that occur and the availability of sufficient water for domestic, industrial and agricultural purposes (Arsyad \& Rustiadi, 2012)

Alfisols are found in most regions North Central states and at mountainous region and consists of $13.5 \%$ of total area in 50 countries. Alfisol occupied $13.2 \%$ of the world surface area (second broad rating) and is found on all continents (Miller \& Donahue, 1990). Alfisol distribution in Indonesia is found on the islands of Java, Nusa Tenggara, and Sulawesi. The total area of Alfisol in Indonesia as a whole is $4.46 \%$ ( $8,525 \mathrm{ha}$ ) which is spread over hilly flat areas (Sudjadi et al. in Sudaryono, 2009). Technically Alfisol has productivity potential which is large for secondary crops, especially maize. The factor that limits the growth of maize is water. The most water requirements in maize plants are in flowering stages and seed filling stages (Muhadjir, 1988).

An alternative technology increase water production is the Deficit Irrigation technology. Deficit irrigation is a new technology in the field of irrigation that allows the plants to experience water stress but does not affect the yield or crop production (Rosadi et al., 2006). The stress exposed by the deficit irrigation technology has a positive effect on the water supply since it can save the water. The results of the study on maize by ShariotUllah et al. (2010) stated that the treatment of a $60 \%$ deficit had higher water productivity than normal irrigation treatment and produced grain yields that were not significantly different. However, the deficit irrigation technology requires accurate evapotranspiration data so that how much the irrigation water is given can be estimated.

According to Handoko (1995), the reference evapotranspiration (ETo) describes the maximum rate of the water loss in a crop determined by the climatic conditions in a tightly closed canopy crop cover with the adequate water supply. The evapotranspiration is influenced by many factors so that the measurement is not straight forward directly, therefore, many estimation models have been developed to overcome this issue.

The use of estimating evapotranspiration rate methods has been carried out in several places in Indonesia, Usman (2004) conducted an analysis of comparing the methods of Thornthwaite, Blaney-Criddle, Samani-Hargreaves, PrestleyTaylor, Jansen-Haise, Penman and PenmannMonteith at five stations climate in West Java. The estimating evapotranspiration method has not considered the physical condition and soil moisture given in the same volume continuously yet. Since the determination of the right estimation method will be very helpful, discovering the right model that can overcome the soil factor in determining the evapotranspiration is needed. This study is intended to determine the actual evapotranspiration model based on the volume of irrigation to obtain an accurate evapotranspiration value on Alfisols with maize plantation.

\section{MATERIALS AND METHODS}

The research was conducted at the Jumantono District $\left(7^{\circ} 37^{\prime} 48.82 \mathrm{~s} S \mathrm{~S}\right.$ and $110^{\circ} 56^{\prime} 52.17 " \mathrm{E}$; 162 masl) from August to November 2017 and has the C3 Climate type Zone according to Oldeman (Kementerian Pertanian, 2015). The soil type is Alfisols with Silty Clay texture $(9.06 \%$ sand, $47.79 \%$ silt, and $43.15 \%$ clay). The physical properties of the soil analyzed were bulk density, particle density, porosity, and $\mathrm{pH}$ carried out in the Physics and Soil Conservation Laboratory, Sebelas Maret University, Surakarta. The 
average bulk density $\left(1.12 \mathrm{~g} \mathrm{~cm}^{-3}\right)$ cured at a depth of $0-25 \mathrm{~cm}$ uses the ring sample method (5 cm diameter and $4 \mathrm{~cm}$ high). Particle density $\left(1.59 \mathrm{~g} \mathrm{~cm}^{-3}\right)$ was measured by the gravimetric method, porosity $(29.7 \%)$ and soil $\mathrm{pH}$ (5.32) which was measured in a ratio of 1 : 2.5 soil:aquadest using $\mathrm{pH}$ meter. The average annual rainfall was around $2070.1 \mathrm{~mm}$ over the last 30 years and in August to November experienced a dry season. Average soil temperature at a depth of $0 \mathrm{~cm}, 2 \mathrm{~cm}, 5 \mathrm{~cm}$, $10 \mathrm{~cm}, 20 \mathrm{~cm}\left(32.4^{\circ} \mathrm{C}, 31.9^{\circ} \mathrm{C}, 30.5^{\circ} \mathrm{C}, 31.4{ }^{\circ} \mathrm{C}\right.$, $\left.28.9{ }^{\circ} \mathrm{C}, 31.0^{\circ} \mathrm{C}\right)$, Air temperature $\left(27.6{ }^{\circ} \mathrm{C}\right)$, irradiation (62.6\%), and wind speed $\left(14.5 \mathrm{~ms}^{-1}\right)$ The surface runoff on the research land can be ignored since it is the flat land (slope $3 \%$ ) so that the rate of rainwater can be completely infiltrated with the infiltration data on the research area $2 \mathrm{~mm}$ day $^{-1}$ (Soemarto, 1987). The research area was fertilized with the basic fertilizer before.

The research design used was Strip-plot design with 5 treatments and 4 replications in each treatment with a size of $3 \times 1.5 \mathrm{~m}$. The treatments include: five levels of irrigation deficit treatment (D) namely D1 (ETc 100\%), D2 (ETC 80\%), D3 (ETC 60\%), D4 (ETC 40\%), and D5 (ETc 20\%). ETc (Crop evapotranspiration) was obtained from the daily crop evapotranspiration of maize with the reference evapotranspiration (ETo) from the evaporation pan class A (diameter $122 \mathrm{~cm}$ and height $25.4 \mathrm{~cm}$ ) of the climatology station of Jumantono. The calculation of the reference evapotranspiration (ETo) with the evaporation pan method done by using the evaporation $(\mathrm{mm})$ from the evaporation pan multiplied by the pan coefficient (0.7). Furthermore, the calculation of crop evapotranspiration (ETc) uses an empirical formula from $F A O$ Irrigation and Drainage Paper No. 56 (Allen et al., 1998). Crop evapotranspiration (ETC) was converted to volume $(\mathrm{mm})$ by multiplying ETc with the area size. However, if the rain comes the deficit irrigation treatment was not given. The irrigation treatment deficit (D) was performed every 2 days starting from the beginning of the season until the end of the planting season using the manual method.

Soil moisture condition was analyzed using the TDR (Time Domain Reflectometry) method with soil moisture probe EC-5 Decagon as a tool combined with the $E M-5 B$ data logger to record and store the data at the depth of $25 \mathrm{~cm}$ from the $3 \mathrm{rd}$ week to the end of the season. The installation of the soil moisture probe was carried out on the third replication in each treatment. The soil moisture content data $\left(\mathrm{m}^{3} \mathrm{~m}^{-3}\right)$ was calculated once every 10 minutes and converted to the daily average converted to $\left(\mathrm{mm} \mathrm{day}^{-1}\right)$.

The groundwater retention is the ability of the soil to retain water. The calculation of soil retention was done using the Soil Water Characteristic Calculator software (Saxton \& Rawls, 2006), where the soil retention calculation uses the sand and clay percentage data from the results of the soil texture analysis using the pipette method.

Crop evapotranspiration (ETc) is a combination of evaporation and transpiration. The calculation of ETc uses an empirical formula with the reference evapotranspiration (ETo) using the Penman-Monteith modification formula. However, the calculation of the reference evapotranspiration of the Penmanmonteith model was facilitated by using the Cropwat v8.0. Furthermore, ETc was calculated using an empirical formula from FAO Irrigation and Drainage Paper No. 56 (Allen et al., 1998). $\mathrm{ETC}=\mathrm{Kc} \times \mathrm{ETo}$

Where $\mathrm{Kc}$ is the coefficient of the maize and ETo is the reference evapotranspiration of the Penman-Monteith model. Maize crop coefficient uses a reference from $F A O$ Irrigation and Drainage Paper No. 56 (Allen et al., 1998) with a little modification so that each growth phase of the Kc value will be different. 
Actual evapotranspiration (ETa) is the evapotranspiration in the limited water supply conditions or significant water loss. The calculation of the actual evapotranspiration using this model is an indirect method while the water balance model is an applicable method on the small area $\left(<10 \mathrm{~mm}^{2}\right)$ or larger catch $\left(<10 \mathrm{~km}^{2}\right)$ (Rana \& Katerji, 2000).

The actual evapotranspiration was calculated using the SWB (Soil water balance) (Allen et al., 1998) formula as follow:

$$
\mathrm{ETa}=\mathrm{R}+\mathrm{I}+\Delta \mathrm{SM}-\mathrm{Dp}-\mathrm{RO}+\mathrm{CR}
$$

The calculation of the soil moisture content $(\triangle \mathrm{SM})$ was calculated between 2 days ( $i$ and $i-1$ ) using the formula

\section{$\Delta \mathrm{SM}=\left(\mathrm{S}_{\left.\mathrm{i}-\mathrm{S}_{\mathrm{i}-1}\right)}\right)$}

Where ETa is the actual evapotranspiration $(\mathrm{mm}), R$ is rainfall $(\mathrm{mm})$, $\triangle S M$ is a change in the soil moisture content $\left(\mathrm{mm}\right.$ day $\left.^{-1}\right), \mathrm{Dp}$ is deep percolation $(\mathrm{mm}), \mathrm{RO}$ is surface runoff $(\mathrm{mm}), C R$ is capillary flow $(\mathrm{mm})$ and $S$ is soil moisture content $(\mathrm{mm})$. The surface runoff (RO) is neglected because the study area belongs to semi-arid and very small slopes (Holmes, 1984). The capillary rise fluxes are also ignored because they are shallow and do not contribute to the groundwater into the root zone $(30 \mathrm{~cm}$ ) (Ridolfi et al., 2008). The percolation was considered 0 if the soil moisture content is below the field capacity (i.e., SMC $<\mathrm{pF} 2.5$ ). The research has relatively hard soil so the percolation is considered low due to the plowing and percolation was simulated less than $4 \mathrm{~mm}$ (Direktorat Jenderal Sumberdaya Air, 2013; Notohadiprawiro, 2006: Rizal et al., 2014). If the moisture content exceeds the field capacity ( $>$ pF 2.5) the percolation will be calculated as $2 \mathrm{~mm}$ because of the clay texture (Soemarto, 1987). $\triangle S M$ can be negative or positive. So the calculation of the actual evapotranspiration can be simplified into :

$\mathrm{ETa}=\mathrm{R}+\mathrm{I}+\Delta \mathrm{SM}$
If the moisture content does not exceed the field capacity $(<\mathrm{pF} 2.54)$ and

$$
\mathrm{ETa}=\mathbf{R}+\mathbf{I}+\Delta \mathrm{SM}-\mathrm{Dp}
$$

If the water supply exceeds the field capacity (>pF 2.54).

The calculated rainfall value that is considered to enter the root zone is by reducing the highest moisture with the lowest moisture.

The climatological data on the study area are observed by the tools at the Jumantono climatology station. The temperature was observed with a maximum and minimum thermometer type six, the humidity using thermohygrograph, the rainfall using ombrometer, the length of sunshine using the Sunshine recorder type Campbell Stokes and the evaporation using the evaporation pans class $\mathrm{A}$.

\section{Model Description}

The determination of the actual evapotranspiration model based on the volume of the irrigation using the volume variables of irrigation (\% ETc) and crop evapotranspiration (ETc) with the reference evapotranspiration (ETo) Penman-Monteith model. The actual evapotranspiration model uses the formula:

\section{$\mathrm{ETa}=\mathrm{X}$. Irrigation Volume.ETc}

The soil correction factor $(X)$ was calculated using the formula:

$\mathrm{X}=\frac{E T c}{E T a}$

Where ETc is crop evapotranspiration (ETc) and ETa is the actual evapotranspiration $(\mathrm{mm})$ which was calculated using the SWB approach. The soil correction factor $(X)$ is then analyzed using the simple linear regression using the scatter plot so that the equation was found. The model was made into 3 types; daily, weekly and total one planting season. The daily model uses the average daily correction factor for one season, a weekly model using the average correction factor 
every week and total model using the number of evapotranspiration in one planting season.

\section{Statistical Evaluation}

The statistical evaluation is carried out to examine the comparison of actual evapotranspiration and model using the mean value between the compared model, standard deviation, interception and slope angle in linear regression, and RMSE (Root Mean Square Error) to estimate the average error of the variance (Willmott, 1982) analysis using Microsoft Excel.RMSE is the average difference between 2 model values, if the value is lower then it shows the better suitability between the 2 average values between the models compared. A good model produces an RMSE that is close to 0.

The RMSE of a model prediction with respect to the estimated variable $X_{\text {model }}$ is defined as the square root of the mean squared error as follow:

$$
R M S E=\sqrt{\frac{\sum_{i=1}^{n}\left(X_{o b s, i}-X_{\text {model }, i}\right)^{2}}{n}}
$$

where $X_{o b s}$ is observed actual evapotranspiration and $X_{\text {model }}$ is modeled actual evapotranspiration at time/place $i$.

The effects of the irrigation treatment on the actual evapotranspiration were tested using $f$ test. If the data are normally distributed and have a real effect, it is continued with further testing of LSD at the level of $5 \%$.

\section{RESULTS}

\section{Crop Evapotranspiration (ETc) and Actual Evapotranspiration (ETa)}
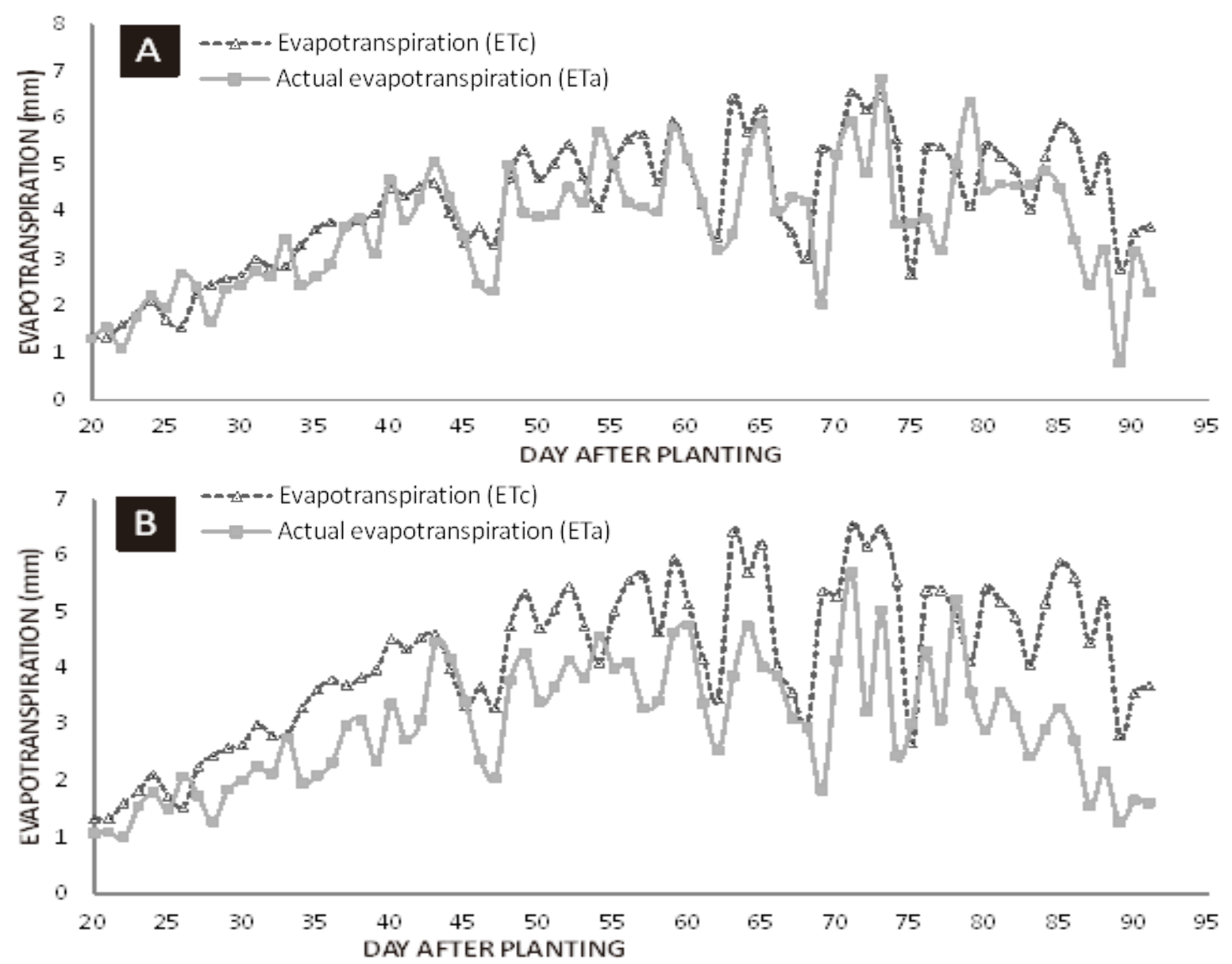

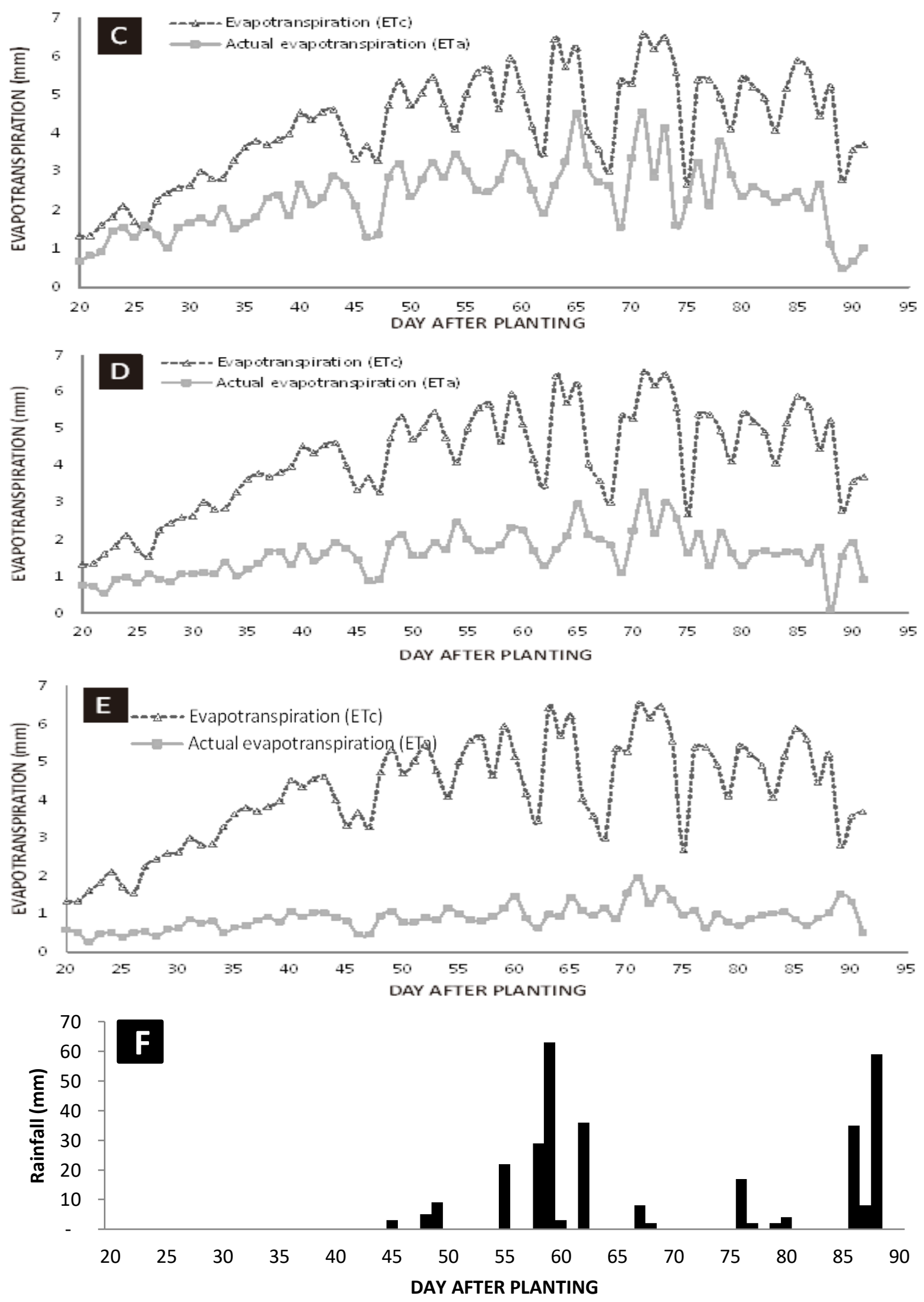

Figure 1. Crop evapotranspiration, actual evapotranspiration, and the rainfall during the research (a) ETc $100 \%$, (b) ETc $80 \%$, (c) ETc 60\%, (d) ETc 40\%, (e) ETc $20 \%$ and (f) Rainfall 


\section{RESEARCH ARTICLE}

Figure 1 shows that the actual evapotranspiration (ETa) was smaller than crop evapotranspiration (ETC) in all treatments. The dynamics between crop evapotranspiration (ETc) and actual evapotranspiration (ETa) almost show the same fluctuations. Total one planting season of the maize crop evapotranspiration (ETc) was $301.42 \mathrm{~mm}$. The highest and lowest daily crop evapotranspiration (ETc) is $6.55 \mathrm{~mm}$ and 1.34 $\mathrm{mm}$, respectively. Meanwhile, the average daily crop evapotranspiration (ETc) was $4.19 \mathrm{~mm}$.

The actual plowing dynamics experience fluctuations in all treatments. The highest actual evapotranspiration occurred in treatment D1 (ETc 100\%) which was $7.03 \mathrm{~mm}$ $\mathrm{day}^{-1}$ on the day after planting (DAP) 73 while the lowest actual evapotranspiration occurred in treatment D4 (ETc 40\%) was $0.08 \mathrm{~mm} \mathrm{day}^{-1}$ on DAP 89. At DAP 20 up to DAP 51, the actual evapotranspiration in all treatments tends to increase. Furthermore, at DAP 51 to DAP 75, the actual evapotranspiration in all treatments is very volatile. It happens due to there has been a rain event which will significantly affect moisture levels. In addition, the actual evapotranspiration in all treatments tends to decrease on DAP 76 to DAP 91. The average of each actual evapotranspiration for each treatment D1, D2, D3, D4, D5 are $4.23 \mathrm{~mm}$, $3.42 \mathrm{~mm}, 2.55 \mathrm{~mm}, 1.75 \mathrm{~mm}$ and $0.99 \mathrm{~mm}$.

The treatment which demonstrates a high fluctuating trend was found in the treatment D1 (ETC 100\%) where there are extremely high data $(6.85 \mathrm{~mm})$ and extremely low data $(0.08 \mathrm{~mm}$ ). Besides, D5 (20\% ETc) was the lowest fluctuation trend found. The highest of the actual evapotranspiration occurs due to the large irrigation water supply of $6.55 \mathrm{~mm}$. Meanwhile, the lowest occurs when there is rain, for example on DAP 89 there is $59 \mathrm{~mm}$ rain resulting in the actual evapotranspiration in treatment D1 (ETc 100\%) being the minimum that was $0.80 \mathrm{~mm}$. The actual evapotranspiration in treatment D4 (ETC 40\%) and D5 (ETC 20\%) experience the stress at the beginning of growth until the end of growth, resulting in low fluctuations because they tend to be at the minimum $(0.08 \mathrm{~mm}$ $3.29 \mathrm{~mm})$.

\section{The Effects of the Treatment on the Actual Evapotranspiration}

Table 1. The effects of the deficit irrigation treatment on the actual evapotranspiration $(\mathrm{mm})$

\begin{tabular}{cccccc}
\hline \multirow{2}{*}{ Week } & \multicolumn{5}{c}{ Treatment } \\
\cline { 2 - 6 } & ETc 100\% & ETc 80\% & ETc 60\% & ETc 40\% & ETc 20\% \\
\hline $\mathbf{3}$ & $1.84 \mathrm{a}$ & $1.47 \mathrm{~b}$ & $1.20 \mathrm{c}$ & $0.84 \mathrm{~d}$ & $0.47 \mathrm{e}$ \\
$\mathbf{4}$ & $2.79 \mathrm{a}$ & $2.22 \mathrm{~b}$ & $1.74 \mathrm{c}$ & $1.18 \mathrm{~d}$ & $0.71 \mathrm{e}$ \\
$\mathbf{5}$ & $3.95 \mathrm{a}$ & $3.10 \mathrm{~b}$ & $2.41 \mathrm{c}$ & $1.67 \mathrm{~d}$ & $0.90 \mathrm{e}$ \\
$\mathbf{6}$ & $4.18 \mathrm{a}$ & $3.59 \mathrm{~b}$ & $2.41 \mathrm{c}$ & $1.62 \mathrm{~d}$ & $0.90 \mathrm{e}$ \\
$\mathbf{7}$ & $4.70 \mathrm{a}$ & $4.06 \mathrm{~b}$ & $2.80 \mathrm{c}$ & $1.70 \mathrm{~d}$ & $0.84 \mathrm{e}$ \\
$\mathbf{8}$ & $5.16 \mathrm{a}$ & $4.33 \mathrm{~b}$ & $2.84 \mathrm{c}$ & $1.96 \mathrm{~d}$ & $1.10 \mathrm{e}$ \\
$\mathbf{9}$ & $5.06 \mathrm{a}$ & $4.19 \mathrm{ab}$ & $3.24 \mathrm{bc}$ & $2.23 \mathrm{~cd}$ & $1.14 \mathrm{~d}$ \\
$\mathbf{1 0}$ & $5.43 \mathrm{a}$ & $4.27 \mathrm{ab}$ & $4.09 \mathrm{~b}$ & $2.60 \mathrm{c}$ & $1.54 \mathrm{c}$ \\
$\mathbf{1 1}$ & $5.81 \mathrm{a}$ & $4.67 \mathrm{~b}$ & $3.52 \mathrm{c}$ & $2.18 \mathrm{~d}$ & $1.10 \mathrm{e}$ \\
$\mathbf{1 2}$ & $3.46 \mathrm{a}$ & $2.39 \mathrm{ab}$ & $1.95 \mathrm{~b}$ & $1.57 \mathrm{~b}$ & $1.11 \mathrm{~b}$ \\
\hline
\end{tabular}

Remarks: Numbers followed by different letters on the same line are significantly different at the $5 \%$ level, with LSD test 
Table 2. Soil correction factor (X) equation in the daily model, weekly model, and total one planting model

\begin{tabular}{cccc}
\hline \multirow{2}{*}{ Model } & \multicolumn{3}{c}{$\mathrm{y}=\mathrm{a}+\mathrm{bx}$} \\
\cline { 2 - 4 } & $\mathrm{A}$ & $\mathrm{b}$ & $\mathrm{R}^{2}$ \\
\hline Daily Model & 0.046 & 0.0087 & 0.9994 \\
Weekly Model & 0.4428 & 0.0054 & 0.9419 \\
Total Model & 0.0403 & 0.0085 & 0.9998 \\
\hline
\end{tabular}

Table 1 shows that ETc $100 \%$ treatment always shows the highest of all treatments per week. The effect of the irrigation deficit (D) has a significant effect on the actual evapotranspiration ( $p<0.05$ ). In the LSD test, all treatments show differences from the third to the eight weeks. Furthermore, at the ninth and tenth week, the treatment D1 $(5.06 \mathrm{~mm}$ and $5.43 \mathrm{~mm}$ ) did not show a significant difference to the treatment D2 $(4.19 \mathrm{~mm}$ and $4.27 \mathrm{~mm}$ ), yet for the treatment D3 $(3.24 \mathrm{~mm}$ and $4.09 \mathrm{~mm})$, D4 $(2.23 \mathrm{~mm}$ and $2.60 \mathrm{~mm})$, and D5 (1.14 mm and $1.54 \mathrm{~mm} \mathrm{~mm}$ ) show a significant differences. At the eleventh week, all treatments show a huge difference. Furthermore, the twelfth week of D1 treatment $(3.46 \mathrm{~mm})$ show a significant difference to the treatment D3 $(1.95 \mathrm{~mm}), \mathrm{D} 4$ $(1.57 \mathrm{~mm})$ and D5 $(1.11 \mathrm{~mm})$. The results of the correlation analysis show a strong correlation between the volume of the deficit irrigation water and the actual evapotranspiration $(r=0.75)$. Besides, the greater the deficit irrigation, the higher the actual evapotranspiration.

\section{The Actual Evapotranspiration Model}

The correction factors obtained in each treatment were then regressed with the volume of irrigation which produced equations for the daily model, the weekly model and the total model are presented in Table 2.
Table 2 shows that the determination coefficient of all equation models was greater than 0.90 , meaning that $\pm 90 \%$ of the volume irrigation affects the correction factor value while $\pm 10 \%$ is influenced by others. All models show a positive relationship which means that if the volume of irrigation is greater then the correction factor will also be greater. The coefficient (a) in the daily model shows almost the same as the total model, but the weekly model shows the coefficient was 10 times greater than the daily model and the total model. This means that the correction factor in the daily model and the total model if there is no irrigation supply then the correction factor will not increase significantly. But the regression coefficient value (b) in the weekly model shows a value smaller than the daily model and the total model so that the final value of the correction factor still shows the same value.

\section{Statistical evaluation}

The resulting model was then compared with the observed data by looking for RMSE. The results of the model are compared with the actual values of observed on daily, weekly and total one planting season estimation. The RMSE of each model is presented in Table 3, 4 , and 5.

The results of the RMSE analysis of the three models show that the daily model and the total model indicate that the RMSE is almost the same in the daily data. Whereas the weekly model shows the high $(1.54 \mathrm{~mm}$ day $^{-1}$ ) RMSE in the daily estimation. This is because the equation of the correction factor is different between daily and totalwith weekly. Soil correction factor equation in different weekly models results in a higher correction factor than the daily model and the total model. 


\section{RESEARCH ARTICLE}

Table 3. Daily model deviations(RMSE) in daily, weekly and total one planting season estimates

\begin{tabular}{cccc}
\hline \multirow{2}{*}{ Treatment } & \multicolumn{3}{c}{ Estimation $(\mathbf{m m})$} \\
\cline { 2 - 4 } & Daily & Weekly & Total one planting season \\
\hline ETc 100\% & 0.94 & 109.22 & 6.71 \\
ETc 80\% & 0.78 & 87.24 & 7.65 \\
ETc 60\% & 0.64 & 65.17 & 6.38 \\
ETc 40\% & 0.46 & 43.25 & 4.53 \\
ETc 20\% & 0.27 & 21.09 & 2.03 \\
\hline
\end{tabular}

Table 4. Weekly model deviations (RMSE) in daily, weekly and total one planting season estimates

\begin{tabular}{cccc}
\hline \multirow{2}{*}{ Treatment } & \multicolumn{3}{c}{ Estimation $(\mathbf{m m})$} \\
\cline { 2 - 4 } & Daily & Weekly & Total one planting season \\
\hline ETc 100\% & 1.05 & 2.41 & 26 \\
ETc 80\% & 1.07 & 2.77 & 47.68 \\
ETc 60\% & 1.18 & 4.44 & 66.3 \\
ETc 40\% & 1.34 & 7.04 & 84.34 \\
ETc 20\% & 1.54 & 9.58 & 101.34 \\
\hline
\end{tabular}

Table 5. Total model deviations (RMSE) in daily, weekly and total one planting season estimates

\begin{tabular}{cccc}
\hline \multirow{2}{*}{ Treatment } & \multicolumn{3}{c}{ Estimation $(\mathbf{m m})$} \\
\cline { 2 - 4 } & Daily & Weekly & Total one planting season \\
\hline ETc 100\% & 0.93 & 91.9 & 1.04 \\
ETc 80\% & 0.77 & 73.33 & 1.11 \\
ETc 60\% & 0.63 & 54.74 & 1.05 \\
ETc 40\% & 0.45 & 36.29 & 0.4 \\
ETc 20\% & 0.26 & 17.61 & 0.9 \\
\hline
\end{tabular}

The weekly model shows the lowest RMSE on weekly data estimation (2.41 mm $9.58 \mathrm{~mm}$ ) and shows a large RMSE on estimating daily and total. The RMSE in the weekly model was getting smaller in estimating weekly data and getting bigger on daily and total estimates. This is because the weekly correction factor uses weekly data as a divider so that the daily and monthly data will deviate. If the weekly model is used in daily and total estimation it will cause overestimation because the correction factor is also largely due to different a (intercept) and b (slope).

In the daily model and the total one, planting season model shows a high RMSE on the weekly estimation, but the daily model
(109 $\mathrm{mm}$ week $^{-1}$ ) shows a higher RMSE than the total model (91.9 mm week ${ }^{-1}$ ) on weekly estimates. In total estimation, the daily model $(6.71 \mathrm{~mm})$ shows a higher RMSE than the total model $(1.11 \mathrm{~mm})$. Whereas for the RMSE in the daily model and the total model will be smaller if the volume of irrigation is less and less on daily and total estimates.

The results of the RMSE analysis can be made a decision about where to estimate the actual daily and total evapotranspiration, can use the total model because of the small RMSE. Whereas to estimate the actual weekly evapotranspiration value using a weekly model because of the small RMSE. 


\section{DISCUSSION}

The actual evapotranspiration model based on irrigation volume can explain most of the variability in the estimation of actual evapotranspiration on maize fields in Alfisols, Jumantono $\left(R^{2}>90\right)$. The soil correction factor $(X)$ for each irrigation volume in this model is an important element because it was a validation of Penman-Monteith evapotranspiration so that the actual evapotranspiration $e$ is accurate. Soil correction factor produced on all models with optimal irrigation (100\% ETc) shows the same results as the results of the study (Runtunuwu et al., 2008) conducted at the Ciledug Climatology Station and (Li et al., 2016) carried out on maize in Wuwei City, China that was 0.99 which using the Penman-Monteith model as a reference. Soil correction factor decreases if the irrigation volume is also reduced. It because the effect of the irrigation deficit (D) has a significant effect on the actual evapotranspiration ( $p<0.05$ ). One reason for this is that actual evapotranspiration is small when irrigation supplies are limited (Table 1). This is in line with an opinion (Doorenbos \& Kasaam, 1979), maximum evapotranspiration will occur if optimum water availability. Evapotranspiration at 9 and 10 weeks has the highest value because plants are in the midphase so the plant coefficient values are high and constant (1.2).

The total model was the best model for daily and total estimation, although the daily model shows the same RMSE. There are 2 reasons that explain that the total model has better performance; The RMSE on the total model is smaller than the daily RMSE model and the total model integrates the total in each treatment while the daily model integrates the value every day in each treatment so that there are errors caused by rainfall. Rainfall causes the actual evapotranspiration observed tend to decrease because there is no treatment at that time while the crop evapotranspiration (ETC) remains (Figure 1). This is in line with the opinion of (Achmad, 2011) that says if the supply of water is reduced then the evaporation will decrease. But on the following day the actual evapotranspiration rise due to soil moisture which takes time to reach the root zone so that the actual evapotranspiration rises and the evapotranspiration (ETc) remains. So this is in line with (Mastrolili et al., 1998) stating that the high evapotranspiration are obtained from the previous irrigation supplies if the weather parameters do not obstruct the evapotranspiration process and the minimum evapotranspiration occurs on rainy days or periods of stress.

The results indicated that the daily model and the total model showed small RMSE on daily estimation and total estimation. Whereas the weekly model shows high RMSE for daily and total estimation. This is due to the equation of the correction factor in the almost equal daily and total models, whereas in the weekly model correction factor equations tend to be different. The slope on the daily model and the total model shows a small value $(a=0.040-0.046)$, whereas on the weekly model the intercept value was 10 times higher $(a=0.442)$. That is, if the daily and total models are not given irrigation, the correction factor will be small or not increase (0.04), but if there is no irrigation on the weekly model, the correction factor value will be 0.44 or tend to be larger. This will cause an overestimate condition on the weekly model if it is used for daily or total estimation. This means that the weekly model is not appropriate if used in daily and total estimation. While for weekly estimation, it recommends a weekly model because the weekly modeling uses a weekly average and has a small RMSE. 
The RMSE of the total model in daily and total estimation shows that RMSE is getting smaller when the irrigation volume is small. This means that the total accuracy model will be higher when the irrigation volume is getting smaller. Whereas in the weekly model used for weekly estimation the RMSE was high when the irrigation volume is small, which means the less the volume of irrigation, the lower the accuracy. This is due to overestimating the correction factor due to the large value of a (intercept) $(0.4428)$ although there is no irrigation.

Our model can be basic information for the next research. Although our model performs well, our model is limited because the calculation uses the Penman-Monteith model. The consequence of using the Penman-Monteith model is that more data must be needed. Even this model cannot be fully applied in Indonesia, because there are only a few observation stations weather in Indonesia which observes climate variables complete and continuous. The percentage of errors from the total model and the weekly model in estimation is around $1 \%$. The estimation error is still the same as the standard error of $\pm 10 \%$ (Rosenberg et al., 1983).

\section{CONCLUSION}

Actual evapotranspiration model based on irrigation volume of the maize field on Alfisols are (a)for daily and total estimation using model $\mathrm{ETa}=\{0.0403+(0.0085 \times$ Irrigation volume) $\} \times$ ETc and (b) weekly data estimation using model $\mathrm{ETa}=\{0.4428+$ $(0.0054 \times$ Irrigation volume $) \times$ ETc, where irrigation volume in (\% ETc) and ETc using reference evapotranspiration (ETo) with Penmann-Monteith model. The percentage of errors in both models is $1 \%$. Our model can be basic information for the next research. More research with a longer time and in various places (spatiotemporal variability) are needed so that the built model becomes valid.

\section{REFERENCES}

Achmad, M. (2011). Buku Ajar Hidrologi Teknik. Makassar, Indonesia: Universitas Hasanuddin.

Allen, R. G., Pereira, L. S., Raes, D., \& Smith, M. (1998). Crop Evapotranspirationguidelines for computing crop water requirements-FAO Irrigation and Drainage Paper No. 56. Rome, Italy: FAO.

Arsyad, S., \& Rustiadi, E. (2012). Penyelamatan Tanah, Air, dan Lingkungan (2nd ed.). Jakarta: Yayasan Pustaka Obor.

Direktorat Jenderal Sumberdaya Air. (2013). Kriteria Perencanaan: Perencanaan Jaringan Irigasi. Kementerian Pekerjaan Umum. Jakarta, Indonesia: Kementerian Pekerjaan Umum. 230p.

Doorenbos, J., \& Kasaam, A. H. (1979). Yield Response to Water. Rome, Italy: Land and Water Development Division., FAO.

Handoko. (1995). Klimatologi Dasar: Landasan Pemahaman Fisika Atmosfer dan Unsur-unsur Iklim (Second Edi). Jakarta, Indonesia: Dunia Pustaka Jaya.

Holmes, J. W. (1984). Measuring Evapotranspiration By Hydrological Methods. Agricultural Water Management, 8(1-3), 29-40. http://doi.org/10.1016/03783774(84)90044-1

Kementerian Pertanian. (2015). Atlas Peta Pengembangan Kawasan Padi Kabupaten Karanganyar, Provinsi Jawa Tengah. Retrieved June 20, 2018, from http://www1.pertanian.go.id/sikp/files/p jku50/CETAK_KARANGANYAR_FINAL.pdf

Li, S., Kang, S., Zhang, L., Zhang, J., Du, T., Tong, L., \& Ding, R. (2016). Evaluation of Six Potential Evapotranspiration Models for Estimating Crop Potential and Actual Evapotranspiration in Arid Regions. Journal of Hydrology, 543(October), 450461. 10.1016/j.jhydrol.2016.10.022

Mastrolili, M., Katerji, N., Rana, G., \& Nouna, B. (1998). Daily Actual Evpotranspiration Measured By TDR Technology In Mediterranian Conditions. Agric for Meteorology, 90, 81-89. 
Miller, R. W., \& Donahue, R. (1990). Soils : An Introduction to Soils and Plant Growth (6th ed.). New Jersey: Prentice Hall.

Muhadjir, F. (1988). Karakteristik Tanaman Jagung. Bogor, Indonesia: Central Research Institute for Food Crops (CRIFC).

Notohadiprawiro. (2006). Rasionalisasi Penggunaan Sumberdaya Air di Indonesia. Retrieved June 21, 2018, from http://blogugm.azureedge.net/wpcontent/blogs.dir/2601/files/2006/11/19 xx-Rasionalisasi-penggunaansumberdaya-air.pdf

Rana, G., \& N. Katerji. (2000). Measurement and Estimation of Actual Evapotranspiration in the Field Under Mediterranean Climate. European Journal of Agronomy, 13(2-3), 125-153. 10.1016/S1161-0301(00)00070-8

Ridolfi, L., Odorico, P. D., Laio, F., \& Tamea, S. (2008). Coupled Stochastic Dynamics of Water Table and Soil Moisture in Bare Soil Conditions. Water Resources Research, 44, 1-11. 10.1029/2007WR006707

Rizal, F., Alfiansyah, \& Rizalihadi, M. (2014). Analisis Perbandingan Kebutuhan Air Irigasi Tanaman Padi Metode Konvensional dengan Metode SRI Organik. Jurnal Teknik Sipil, 3(4), 67-76.

Rosadi, R., Ridwan, Haryono, N., \& Istiawati, O. (2006). Pengaruh Defisit Evapotranspirasi Dalam Regulated Deficit Irrigation (RDI) Pada Kedelai (Glycine Max[L.] Merr.). Jurnal Keteknikan Pertanian, 20, 27-34.

Rosegrant, M. W., Cai, X., \& Cline, S. A. (2002).
Global Water Outlook To 2025: Averting an Impeding Crisis. A 2020 Vision for Food, Agriculture, and the Environment Initiative. Washington.

Rosenberg, N. J., Blad, B. L., \& Verma, S. B. (1983). Microclimate: The Biological Environment (2nd ed.). New York, USA: John Wiley.

Runtunuwu, E., Syahbuddin, H., \& A. Pramudia. (2005). Validation of Evapotranspiration Prediction Model: An Effort to Complete the National Climate Database System. Jurnal Tanah Dan Iklim, (27), 1-10.

Saxton, K. E., \& Rawls, W. J. (2006). Soil Water Characteristic Estimates by Texture and Organic Matter for Hydrologic Solutions. Soil Science Society of America, 70, 1569-1578. 10.2136/sssaj2005.0117

Shariot-Ullah, M., Mili, A. B., \& M. S. U. Talukder. (2010). Water Productivity of Maize under Deficit Irrigation. Banglades Journal of Agricultural Sciences, 37(1), 712.

Soemarto, C. (1987). Hidrologi Teknik. Surabaya, Indonesia: Usaha Nasional.

Sudaryono. (2009). Kontribusi IImu Tanah dalam Mendorong Pengembangan Agribisnis Kacang Tanah $\mathrm{Di}$ Indonesia. Pengembangan Inovasi Pertanian, 2(4), 258-277.

Usman. (2004). Pengaruh Iklim Terhadap Tanah dan Tanaman. Jakarta. Jakarta: Bumi Aksara.

Willmott, C. J. (1982). Some Comments on the Evaluation of Model Performance. Bulletin American Meteorological Society, 63, 1309-1313. 